\title{
Dexamethasone in the treatment of hypernatraemic dehydration
}

\author{
KHALID N HAQUE \\ Faculty of Medicine, Riyad, Saudi Arabia
}

SUMMARY Ninety infants with severe hypernatraemic dehydration (plasma sodium $>150 \mathrm{mmol} / \mathrm{l}$ ) were studied. Most had had a convulsion before admission. They were allocated to two treatment groups. Both groups received intravenous plasma followed by slow intravenous rehydration and correction of acidosis. In addition, one group received intramuscular phenobarbitone, the other group received dexamethasone $0.3 \mathrm{mg}$ by intramuscular injection every 6 hours for 48 hours. Fewer infants receiving dexamethasone had convulsions during treatment $(18 \%$ compared with $52 \%)$, and fewer $(18 \%)$ of them died than in the group who did not receive dexamethasone $(40 \%)$. Dexamethasone may have a role in the management of hypernatraemic dehydration in infants.

Since the introduction of low-solute milks the incidence of hypernatraemic dehydration has fallen in western countries; however in developing countries ignorance and the increasing use of dried cows' milk has resulted in a large number of cases with high morbidity and mortality. Generally a child is brought to hospital having had at least one convulsion before arrival. As the risk of further convulsions was not being reduced by our standard treatment, ${ }^{1}$ it was decided to use dexamethasone in an attempt to reduce cerebral oedema and prevent further convulsions.

\section{Patients and methods}

During an 11-month period, 90 infants suffering from hypernatraemic dehydration (plasma sodium $>150 \mathrm{mmol} / 1$ and a calculated plasma osmolality $>350 \mathrm{mmol} / \mathrm{kg}$ ) were studied. None of the infants was known to have a history of cerebral or renal abnormality; each had been admitted with gastroenteritis and had moderate or severe dehydrationthat is 10 or $15 \%$. Each infant was allotted alternately to one of two treatment groups (Table 1). Each had a lumbar puncture to exclude meningitis ( 2 cases were excluded), 4 infants had pneumonia in addition to gastroenteritis, and are included in the study. Infants were weighed on admission and then daily. Plasma urea, electrolytes, calcium, and glucose were measured on admission and then daily, or more frequently if necessary. Neurological state was graded according to Banister-that is $\mathbf{0}=$ nothing unusual; $1=$ irritable, or poorly responsive and

\section{Table 1 Treatment regimen}

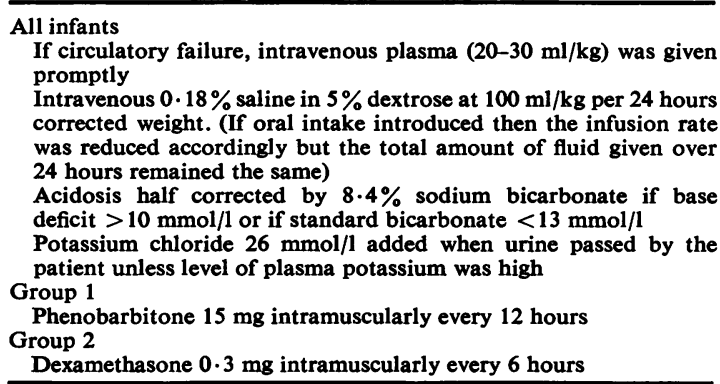

irritable when disturbed; $2=$ increased tone with or without neck stiffness; $3=$ jittery movements, with or without nystagmoid eye movements; $4=$ convulsing.

\section{Results}

Details of patients and their investigations are shown in Table 2. There were 45 infants in each group, all of them were $10 \%$ or more dehydrated, thus all required initial plasma resuscitation. $84 \%$ had convulsed before admission. After admission $18 \%$ of infants in group 2 (who had dexamethasone) had one or more convulsions compared with $52 \%$ in group 1 (Table 3).

Hypocalcaemia. In only 2 infants did the plasma calcium fall below $7 \mathrm{mg} / 100 \mathrm{ml}(1.75 \mathrm{mmol} / \mathrm{l})$; neither infant showed any sign of hypocalcaemia 
Table 2 Details of the two groups of infants

\begin{tabular}{lll}
\hline & $\begin{array}{l}\text { Group 1 } \\
(n=45)\end{array}$ & $\begin{array}{l}\text { Group 2 } \\
(n=45)\end{array}$ \\
\hline Mean age (weeks) & $\begin{array}{c}9 \pm 4 \\
\text { Plasma sodium (mmol/1) }\end{array}$ & $\begin{array}{c}11 \pm 2 \cdot 4 \\
\text { Plasma osmolality* }\end{array}$ \\
Blood urea (mg/100 ml) & $388 \pm 32$ & $390 \pm 20 \cdot 2$ \\
Dehydration 10\% or more & $124 \pm 32$ & $142 \pm 42 \cdot 6$ \\
Plasma resuscitation necessary & 45 & 45 \\
Convulsion before admission & 45 & 45 \\
Mean neurological grade on admission & $39(87 \%)$ & $37(82 \%)$ \\
\hline
\end{tabular}

Conversion: traditional to SI units-blood urea: $1 \mathrm{mg} / 100 \mathrm{ml} \approx 0.166$ $\mathrm{mmol} / 1$.

*Osmolality was calculated ${ }^{8}$ as follows:

$\mathrm{Na}(\mathrm{mmol} / \mathrm{l}) \times 1.9+\mathrm{K}(\mathrm{mmol} / \mathrm{l}) \times 1.9+\mathrm{urea}(\mathrm{mg} / 100 \mathrm{ml}) / 60 \times 10$

$+\operatorname{glucose}(\mathrm{mg} / 100 \mathrm{ml}) / 180 \times 10$.

Table 3 Progress during treatment

\begin{tabular}{|c|c|c|c|}
\hline & \multicolumn{2}{|c|}{ Group I $(n=45)$} & Group $2(n=45$ \\
\hline & No & $(\%)$ & No $(\%)$ \\
\hline $\begin{array}{l}\text { Average percentage weight } \\
\text { increase in first } 24 \text { hours }\end{array}$ & \multicolumn{2}{|c|}{$7 \cdot 5 \pm 2 \cdot 5$} & $6 \cdot 3 \pm 2 \cdot 7$ \\
\hline $\begin{array}{l}\text { No of infants who had con- } \\
\text { vulsions during treatment }\end{array}$ & & & $\begin{array}{l}8 \\
P<0.001\end{array}$ \\
\hline No of infants who aied & 18 & (40) & $\begin{array}{l}8 \\
P<0.001\end{array}$ \\
\hline
\end{tabular}

but each was given intravenous calcium. Both infants were in group 2 receiving phenobarbitone.

Hyperglycaemia. $13 \%$ of infants had high levels of blood sugar ( $>200 \mathrm{mg} / 100 \mathrm{ml} ;>11 \cdot 1 \mathrm{mmol} / \mathrm{l})$ none was given insulin, and the level of blood glucose fell rapidly during rehydration.

Anaemia. Most of the infants in this hospital are anaemic, and these 90 infants had a mean $\mathrm{Hb}$ of 8.6 (range 5.6-12.8) g/dl. 22 infants were each given a blood transfusion during their stay in hospital.

\section{Discussion}

Neurological complications dominate the clinical picture of hypernatraemic dehydration. The risk of permanent damage is greater in the young infant ${ }^{2}$ and in patients with serum sodium of $160 \mathrm{mmol} / \mathrm{l}$ or more. ${ }^{3}$ Permanent neurological deficit is said to occur in 11 to $15 \%$ of such infants. ${ }^{4}$ Convulsions in hypernatraemia are thought to be due to cerebral oedema. $^{5-7}$
Our trial showed that dexamethasone used in conjunction with slow rehydration $(0 \cdot 18 \%$ saline in $5 \%$ dextrose) was associated with fewer convulsions and a lower mortality rate. It seems that the mortality rate may be related to reduction of the cerebral oedema. Our mortality rates are still unacceptably high but this is due mainly to the delay in the infants coming to the hospital; $84 \%$ had convulsed before coming to the hospital. Nevertheless, the $18 \%$ mortality rate of the dexamethasone group is similar to that reported 16 years ago in the UK. ${ }^{2}$ This is remarkable since most of our infants arrived in moribund condition or were malnourished.

Although we feel that dexamethasone may have a role in the management of hypernatraemic dehydration, the best answer lies in prevention and in trying to undo the damage which bottle feeding has caused in developing countries. Further education of the mothers is needed together with restriction of high-solute milk products.

I thank Dr Hussain Showail, Director General, Maternity and Children's Hospital, for allowing me to do this study, my junior colleagues, and the nursing staff.

\section{References}

1 Banister A, Matin-Siddiqi S A, Hatcher G W. Treatment of hypernatraemic dehydration in infancy. Arch Dis Child 1975; 50: 179-86.

${ }^{2}$ Morris Jones P H, Houston I B, Evans R C. Prognosis of the neurological complications of acute hypernatraemia. Lancet 1967; ii: 1385-9.

3 Macaulay D, Watson M. Hypernatraemia in infants as a cause of brain damage. Arch Dis Child 1967; 42: 485-91.

4 Hogan G R. Hypernatremia-problems in management. Pediatr Clin North Am 1976; 23: 569-74.

5 Skinner A L, Moll F C. Hypernatremia accompanying infant diarrhea. Am J Dis Child 1956; 92: 562-75.

6 Weil W B, Wallace W M. Hypertonic dehydration in infancy. Pediatrics 1956; 17: 171-83.

7 Hogan G R, Dodge P R, Gill S R, Master S, Sotos J F. Pathogenisis of seizures occurring during restoration of plasma tonicity to normal in animals previously chronically hypernatremic. Pediatrics $1969 ;$ 43: 54-64.

8 Wood B, ed. Fluid and electrolytes. In: A paediatric vademecum. London: Lloyd-Luke, 1974: 37.

Correspondence to Dr Khalid Haque, Faculty of Medicine, PO Box 2925, Riyad, Saudi Arabia.

Received 5 December 1979 